\title{
H2BC8 wt Allele
}

National Cancer Institute

\section{Source}

National Cancer Institute. H2BC8 wt Allele. NCI Thesaurus. Code C162931.

Human $\mathrm{H} 2 \mathrm{BC} 8$ wild-type allele is located in the vicinity of $6 \mathrm{p} 22.2$ and is approximately 2 $\mathrm{kb}$ in length. This allele, which encodes histone H2B type 1-C/E/F/G/I protein, is involved in histone complex formation. 